\title{
Analysis of the Fatality Rates of Boat and Ferry Accident on Inland Waterways in Nigeria
}

\author{
Ibeawuchi C. Nze. \\ Department of Maritime Management Technology.Federal University of Technology, Owerri
}

\begin{abstract}
This study aims at quantifying the boat and Ferry accident fatality rates on Inland waterways in Nigeria, with a special focus on the waterways of Port Harcourt. With the aid of Simple percentile analysis, a comparative study was carried out to reveal the fatality rate between Boat and Ferry accidents. It was found out that more fatal accidents occurred with the use of Boats than Ferries on the waterways. A total fatality rate of $19 \%$ and 6\% was derived for Boat and Ferry accidents respectively. The economic effect will be a rise in the patronage of Ferry services on the waterways.
\end{abstract}

Keywords: Inland waterways, Boat, Ferry, Fatality rate, Economic.

\subsection{BACKGROUND IN FORMATION}

\section{Introduction}

Inland waterways have a unique role in Nigeria transportation system. Except for the multipurpose projects that provide benefits such as hydro power and flood protection, commercial navigation is the justification for Federal government investment in water ways. With the advent of cabotage and the dredging of the lower Niger river, the water ways system have been improved to facilitate transportation of freight and passengers. In many cases, the underlying reason for doing so - and an expressed purpose for improvement of certain rivers - has been economic development. All transport modes contribute to economic development.

Similar to rail roads, water way traffic is predominantly freight, even through there is a high degree of usage for the carriage of persons. The freight and passenger statistics form the basis for most evaluations of waterways. Similar to highways, some water ways have a high level of other public and personal uses. The pools created by dams are some times use for water supply purposes. Recreation use is widespread, but not quantified except for isolated statistics such as recreational craft use of locks. There is also a perception that freight statistics understate the value of waterways for defense use, because waterways have a unique ability to handle over size shipments and to absorb traffic surges due to mobilization or modal shift. The importance of inland water ways range from resource to economic development, and defense as well as commercial transportation. As result, inland water ways are generally viewed as something more than a part of the transportation system.

The use of water ways is one of transportation alternatives available to most shippers but it is an integral part of the overall transportation system. It is predominantly intermodal transportation because a high percentage of waterway traffic is interchanged with other transportation modes. For the shippers who can use the water way system, it provides a low-cost alternative. Inland waterway transportation ranks at or near the top among other transportation modes in terms of ton-miles produced per unit of energy consumed, and the number of employees and man-hours as well as other resource inputs. It is an important factor in assuring the Nation of a highly competitive and efficient transportation system.

With inland navigable water ways of about $10,000 \mathrm{~km}$ and an extensive coastland of about $852 \mathrm{~km}$, Nigeria has a great potential in the movement of goods from the coast to the hinter land by water transport. The country's water ways centre on the Rivers Niger and Benue which dissect Nigeria into East, West and Northern regions. The two rivers form a confluence at Lokoja and flow into the Atlantic Ocean. The coastal water ways extend from Badagry through Warri to Calabar (NIWA, 2006).

The Nigerian inland water ways have great potentials. The areas adjacent to the rivers are major agricultural areas. Agricultural products from the middle belt areas can be transported to the delta areas through the water ways and vice versa. The importation of raw materials through the ports in the delta areas for use at the Ajaokuta steel complex, which is a major industrial centre on the Niger, will benefit from the importation and export of cargo movement on the waterways.

In all, Nigeria has about $2,200 \mathrm{~km}$ of route, out of the total drainage of the rivers from source to month. The system is connected to about $880 \mathrm{~km}$ of inter-coastal water ways from Lagos through Warri, Port Harcourt and calabar. With a total of approximately $3000 \mathrm{~km}$ of under developed but developable and navigable inland water ways, if fully harnessed, should be poised for a verile commercial river transportation and great potential for inter modernism in the country. Therefore the accruable benefits of our water ways could be maximized from its vast potentials through proper exploitation and development. 
No wonder, in the year 1953 when AlhajiTafawabalewa visited the United States of America, he observed the enormous contribution of the Missipi River to the US economic development and became convinced that the Niger and Benue rivers could play a similar role. Subsequently, the Netherland Engineering Company (NEDECO) were contracted to provide a feasibility study of water ways development which they carried out in series of reports: 1955, 1959, 1961.

As a follow-up to the draft Environmental Impact Assessment (EIA) report, the dredging of the river was first carried out in 1958 by NEDECO and secondly by a consortium of LCHP and Westminster Dredging company in 1978 from Baro through Lokoja to Onitsha, Onya to Warri and Port Harcourt (Wikipedia, 2011).

Although the nation inland water ways operation has been in existerice since the colonial era, the National Inland Waterways Authority (NIWA) formally the Inland Waterways Department (IWD) under the Federal Ministry of transport, was set up in 1956. As a statutory body, $100 \%$ owned by the Federal government, NIWA was established by Decree No. 13 of 1997. With head office at Lokoja and thirteen area offices across the country, the mission and objectives among others include; to provide regulation, economical and operational leadership in the nations inland waterways system and develop infrastructural facilities for efficient international transportation system in line with global best practices that is safe, seamless and affordable. In addition, the authority is to improve and develop the inland waterways for navigation, provide alternative mode of transportation for evacuation of economic goods and persons and execute the objective of Transport especially as it concerns inland waterways.

\subsection{PROBLEM STATEMENT}

Although, inland waterways provide cheaper means of transport and also open up economic activities, we cannot neglect the costs attached to its operation. According to (Ogwude, 1993) the advent of mechanized transport has both increased our mobility and enriched our lives by widened experience; but it has also increase the price of transport usage in terms of human lives and sufferings due to accidents.

The valuation of waterways transport accident reduction can be viewed as resource cost or as an investment appraisal item. As a resource cost, it can be used to evaluate the cost associated with accident in terms of human and material losses. But its interpretation as an investment appraisal item is perhaps more important. This means that it can be used to assess the achievements of transport safety measures and the relative benefit of alternative transport programmes and policies (Ogwude, 1993).

Other studies have investigated the determinants of the vessel accident oil spillage of oil-cargo vessel (Tally et al, 2001, Anderson and Tally, 1995). They revealed that oil-spillage is greater for collision and materials/equipment failure accidents with regards to tank barge accidents.

However, this study attempts to capture the percentage change between the fatal and non-fatal accidents in Nigeria waterways, specifically the Port Harcourt waterways. This will bridge the gap created between previous researches.

\subsection{OBJECTIVE OF THE STUDY}

The main objective of this study is to analyse the effect of vessel accident on inland waterways operation in Nigeria.

The specific objective is:To quantify the degree of change between fatal and non-fatal accidents in Port Harcourt waterways.

\subsection{RESEARCH QUESTION}

Is there a significant change between fatal and non-fatal accidents in Port Harcourt waterways?

\subsection{SIGNIFICANCE OF THE STUDY}

The study is invaluable for policy makers, the academia as well as shippers, operators and the general public,since inland waterways transport is relevant to the socio-economic development of Nigeria.

\section{Literature Review \\ 2.1 REVIEW OF VESSEL ACCIDENT AND OIL SPILLAGE.}

According to Tally (2001) the vessel accident oil-spillage literature has focused on oil-cargo vessels, tankers and tank barges, implicitly assuming that these vessels incurgreater accident oil-spillage than the other (i.e, non-oil-cargo) vessels which just carry oil in their fuel tanks. Anderson (1995) investigates the validity of this assumption for the post US OPA-90 (oil pollution Act of 19900 period by investigating determinants of vessel accident oil spillage, where one of the hypothesized determinants is type of vessel (including both oilcargo and non-oil-cargo vessels). Tobit regression estimates of vessels accident oil-spillage functions suggest that tank barges have incurred greater in-water and out-water oil-spillage for the post OPA-90 period than non- 
oil-cargo vessels (except for freight ships). The policy implication is that greater attention needs to be given to reducing tank barge accident oil-spillage in the post OPA-90 period.

A vessel may spill oil internationally or accidentally. Intentional spillage is typically operational dumping, e.g after discharging its oil cargo, a vessel takes ballast water into its cargo tanks to ensure stability on the return trip, but then dumps the dirty ballast, waster-in-oil mixture, on or before arrival at the loading port. Accidental spillage may occur during the transfer of oil from a vessel accident. US public concern for oil-spillage from vessel accidents has intensified since the tanker vessel, the Exxon Valdez, ran aground in Alaska in March 1989, spilling nearly 11 million gallons of oil into price William sound (Brown, 1996).

\subsection{THE SEVEVERITY OF CRUISE VESSEL ACCIDENTS}

Talley et al (2000) investigates determinants of the property damage and injury severities of cruise vessel accidents. In his study, detailed data of individual cruise vessel accidents for the 11-year time period (1991-2001) that were investigated by U.S Coast Guard were used to estimate cruise-vessel accident property damage and injury severity equations. The estimation results suggest that cruise vessel damage cost per vessel gross ton is greater for: allusion, collision, equipment-failure, explosion, fire, flooding, and grounding cruse vessel accident than for other types of accidents and human cause. The accident injury severity is greater for ocean cruise than for inland water way and harbor / dinner cruise vessel accidents and human cause. The unit damage cost of $\$ 207$ for explosion accidents is greater than that for other types of accidents. If the accident is caused by a human factor, the probability of non-fatal and fatal injuries increases by 0.0877 and 0.0077 , respectively. Staff (1998) investigates the determinants of property damage and injury severities of cruise vessel accidents. He identified three types of cruise vessels (ocean, inland waterway, and harbor / dinner) in his study.

\section{Methodology}

Data used was from secondary sources through the National inland waterways Authority (NIWA). The data set for fatal and non-fatal accidents for the period 2004-2009 were analysed with the use of simple percentile analysis.

\section{Data analysis and presentation}

TABLE 1. STATISTICS OF BOAT ACCIDENT WITHIN THE PORT HARCOURT WATERWAYS

\begin{tabular}{|l|l|l|l|l|l|}
\hline S/No & Year & No of Boat involved & Non-fatal accident & Fatal accident & $\% \Delta$ accident fatality \\
\hline 1 & 2004 & 78 & 44 & 27 & -63.0 \\
\hline 2 & 2005 & 83 & 36 & 41 & 12.2 \\
\hline 3 & 2006 & 64 & 18 & 25 & 28 \\
\hline 4 & 2007 & 56 & 12 & 21 & 43 \\
\hline 5 & 2008 & 39 & 07 & 16 & 56.3 \\
\hline 6 & 2009 & 41 & 10 & 27 & 62 \\
\hline & Total & 361 & 127 & 157 & 19.1 \\
\hline
\end{tabular}

Source: computed from NIWA Port Harcourt

Table 1 above, shows a comparative analysis of boat accident fatality rate between year 2004 and 2009 with respect to inland waterways operation in river state the table reveals an accident fatality rate of $-63 \%$ in the base year 2004.

This implies that there were more survivors (non-fatal cases) than deaths, even though 78 boats were involved in accidents.

However, year 2005 to 2009 witnessed a sharp rise in fatality rate; from $12.2 \%$ to $63 \%$. The fatality rate was $28 \%$ in $2006,43 \%$ in 2007 and $56.3 \%$ in 2008. A total fatality rate of $19 \%$ in boat accident was witnessed during the period.

\section{TABLE 2: STATISTICS OF FERRY ACCIDENTS IN PORT-HARCOURT WATERWAYS.}

\begin{tabular}{|c|c|c|c|c|c|}
\hline S/No & Year & No of Ferry involved & $\begin{array}{l}\text { Non-fatal } \\
\text { accident }\end{array}$ & Fatal accident & $\% \Delta$ accident fatality \\
\hline 1 & 2004 & 63 & 21 & 18 & -16.7 \\
\hline 2 & 2005 & 48 & 48 & 29 & -65.5 \\
\hline 3 & 2006 & 51 & 34 & 26 & -30.8 \\
\hline 4 & 2007 & 46 & 17 & 37 & 54.1 \\
\hline 5 & 2008 & 32 & 12 & 21 & 42.9 \\
\hline \multirow[t]{2}{*}{6} & 2009 & 35 & 10 & 20 & 50 \\
\hline & Total & 275 & 142 & 151 & 6 \\
\hline
\end{tabular}

Source: NIWA Port Harcourt table 2.

The comparative analysis of ferry accident fatality rate for the time period 2004 to 2009 is shown in 
The fatality rate of ferry accident did not follow a regular pattern between year 2004 and 2009. It was $16.7 \%$ in $2004,-65.5 \%$ in $2005,-30.8 \%$ in $2006,54.1 \%$ in $2007,42.9 \%$ in 2008 and $50 \%$ in 2009 . The total fatality rate for the period was about $6 \%$.

\section{Summary of Results}

The results of the analysis shows that there is a fatality rate of approximately $19 \%$ in Boat accidents between the study period (2004-2009). This accident involved a total number of 320 boats (including those propelled by oars) as shown in Table 1 .

Comparatively, Fatality rate of Ferry accidents in Table 2 is approximately $6 \%$. The Tables show that there is a significant change between non-fatal and fatal accidents. This goes a long way to answering the research question set earlier in this study: Is there a significant change between fatal and non-fatal accidents within Port Harcourt waterways?

\subsection{CONCLUSION}

Based on the results of the analysis, we may infer that fatality rate of Boat accident was negligible in the base year 2004 but escalated in 2009 with a rate of $63 \%$. This may imply that safety standards reduced from 2004 to 2009. It may also be as a result of the use of worn-out boats. Human factor errors could be a major contributing factor, as most of the boat drivers carry passengers even when they are under the influence of alcohol.

With respect to Ferry accidents, there was an irregular trend in the fatality rate. Fewer fatality rates as were observed in 2004, 2005, and 2006 gave negative values. This led to the total reduction of fatality rate to a value of $6 \%$. Comparatively, the results reveal that more accidents occurred with the operation of boats along the waterways than ferry operations this may further reveal that sea worthy ferries were employed in the waterways transport. The economic effect is that there will be rise in patronage in ferry services in the near future due to reduced fatality rate.

\subsection{RECOMMENDATIONS}

It is recommended that;

- Engine propelled boats be utilized on the waterways

- Out-dated boats should be scrapped and new ones acquired for replacement

- Boat drivers should be sensitized in a workshop organized by NIWA, for safe operations.

- NIWA and other regulatory bodies like NIMASA should ensure that the waterways are maintained and made navigable at all times.

\section{References}

[1]. Anderson, E.E., Talley, W.K, 1995. The oil spill size of tanker and barge accidents: Determinants and policy implications. Land Economics 71, 216-228

[2]. Brown, R.S., Savage, I., 1996. The economics of double-hulled tankers. Maritime Policy and Management 23, 167-175.

[3]. Greene, W.H., 1997. Econometric Analysis, $3^{\text {rd }}$ Edition, Prentice Hall, Upper Saddle River, NJ.

[4]. Ogwude, I.C., 1993. Topics on Economic Assessments in Transport planning and Management. Transport Working paper N0. 1 Department of Transport Management Technology FUT, Owerri. November.

[5]. Staff, 1998. Human error causes most sea accidents. Journal of Commerce, April 7, 5 A

[6]. National Inland Waterways Authority (NIWA). Annual Reports.

[7]. Wikipedia (2011). The Niger River. Free Encyclopedia. 